\title{
ASSESSMENT OF THE POTENTIAL ANTITUMOR EFFECTS OF GLINUS OPPOSITIFOLIUS (L.) AUG. DC. EXTRACTS
}

\author{
ALEXANDRU VASINCU ${ }^{1}$, DANIELA-CARMEN ABABEI ${ }^{1}$, ANCA MIRON ${ }^{1}{ }^{*}$, MONICA $^{2}$ \\ NEAMŢU ${ }^{1}$, IOANA-MIRELA VASINCU ${ }^{1}$, CHRISTIANA CHARALAMBOUS ${ }^{2}$, CHRISTIANA \\ M. NEOPHYTOU ${ }^{3}$, ANDREAS I. CONSTANTINOU ${ }^{3}$ \\ 1 "Grigore T. Popa" University of Medicine and Pharmacy Iasi, Faculty of Pharmacy, 16 Universitătii Street, 700115, Iași, Romania \\ ${ }^{2}$ University of Nicosia, Medical School, 93 Agiou Nikolaou Street, Engomi 2408 Nicosia, Cyprus \\ ${ }^{3}$ University of Cyprus, Department of Biological Sciences, 75 Kallipoleos Street, 1678 Nicosia, Cyprus
}

*corresponding author: anca.miron@umfiasi.ro

Manuscript received: November 2018

\begin{abstract}
The present study aimed to investigate the antitumor activity of two extracts obtained from Glinus oppositifolius aerial parts in MCF-7, A549, PC3 and CACO2 cancer cell lines using the cell viability, cell cycle and DCFH-DA assays. FT-IR analysis revealed triterpenes and carbohydrates in both extracts and sterols in the ethanolic one. The results from the viability assay showed that the aqueous extract had a promising cytotoxic effect on $\mathrm{CACO} 2$ cells $\left(\mathrm{IC}_{50}=97.69 \pm 2.03 \mu \mathrm{g} / \mathrm{mL}\right)$. Induction of apoptosis in $\mathrm{CACO} 2$ cells was supported by an increase in the cell population in the sub-G1 phase $(55.7 \pm 4.03 \%$ vs. $8.35 \pm$ $3.85 \%$ in control). The DCFH-DA assay revealed that another possible mechanism by which the aqueous extract reduced CACO2 cell viability was an increase in the intracellular oxidative stress. Further in vitro studies are necessary to elucidate other mechanisms underlying the antitumor activity and thus to find new possible therapeutic applications of this plant.
\end{abstract}

\section{Rezumat}

Prezentul studiu a investigat activitatea antitumorală a două extracte obţinute din partea aeriană a speciei Glinus oppositifolius faţă de liniile celulare tumorale MCF-7, A549, PC3 şi CACO2, folosind testul de viabilitate celulară, analiza ciclului celular şi testul DCFH-DA. Analiza FT-IR a evidenţiat triterpene şi carbohidraţi în ambele extracte şi steroli în extractul etanolic. Testul de viabilitate celulară a evidenţiat un efect citotoxic promiţător al extractului apos asupra celulelor $\mathrm{CACO} 2\left(\mathrm{CI}_{50}=97,69 \pm 2,03\right.$ $\mu \mathrm{g} / \mathrm{mL}$ ). A fost observată inducerea apoptozei în celulele CACO2, prin creşterea populaţiei celulare aflate în faza sub-G1 $(55,7 \pm 4,03 \%$ vs. $8,35 \pm 3,85 \%$ în martor). Testul DCFH-DA a evidenţiat faptul că un alt posibil mecanism prin care extractul apos reduce viabilitatea celulelor $\mathrm{CACO} 2$ este creşterea stresului oxidativ intracelular. Viitoare studii in vitro sunt necesare pentru a elucida alte mecanisme implicate în activitatea antitumorală şi pentru a identifica noi posibile utilizări terapeutice ale plantei.

Keywords: Glinus oppositifolius, MTT assay, cell cycle, DCFH-DA assay

\section{Introduction}

Glinus oppositifolius (L.) AUG DC. sin. Molugo oppositifolia (Molluginaceae) is used in the traditional medicine in Mali in the treatment of several diseases that are related to the immune response: intestinal pain and parasitosis, diarrhoea, joint pain, inflammation, fever, skin diseases, wounds, malaria, urinary infections or liver dysfunctions [16, 17]. For abdominal pain and jaundice, the powder, obtained from the dried aerial parts of the plant, is added to food. An aqueous or oily macerate of the plant material is used to treat open wounds and the juice obtained by cold pressing is used to treat some skin disorders [15].

The aerial parts of Glinus oppositifolius were reported to contain triterpene saponins and glycosides of vitexin [30]. Two pectic polysaccharides were isolated from the hot aqueous extract $\left(50^{\circ} \mathrm{C}\right)$ of the aerial parts and their structures have been partially characterized [16]. Previous studies demonstrated that these poly- saccharides possess immunomodulating properties consisting in dose-dependent complement fixation activity and induction of chemotaxis of macrophages, T lymphocytes and NK cells $[15,17]$. Kandar et al. evaluated the antitumor activity of the methanolic extract from the aerial parts of the plant. Three doses of 100,200 and $400 \mathrm{mg} / \mathrm{kg}$ b.w. were administered for 10 days to Ehrlich ascites carcinoma bearing Swiss albino mice. The tumour volume and the percentage of viable cells in the ascitic fluid were significantly reduced in the mice treated with the methanolic extract in comparison with those treated with the standard anticancer drug, 5-fluorouracil, administered in the same conditions at a dose of $2 \mathrm{mg} / \mathrm{kg}$ b.w. [21]. The present study investigated the antitumor activity of the aqueous and ethanolic extracts obtained from Glinus oppositifolius aerial parts in order to find new possible therapeutic applications of this plant. 
FARMACIA, 2019, Vol. 67, 4

\section{Materials and Methods}

\section{Plant material}

Aerial parts of Glinus oppositifolius were supplied by the Department of Traditional Medicine, Bamako, Mali. The identity of the plant material was confirmed by Prof. dr. Drissa Diallo, Director of the Department of Traditional Medicine in Bamako, Mali.

Preparation of extracts

The aqueous (GA) and ethanolic (GE) extracts were obtained as follows: dried and powdered aerial parts $(100 \mathrm{~g})$ were extracted with water $(2 \times 2000 \mathrm{~mL}$, each time for $4 \mathrm{~h}$ ) under reflux in a $50^{\circ} \mathrm{C}$ water bath. Another part of the row material $(100 \mathrm{~g})$ was extracted with ethanol at room temperature $(2 \times 2000 \mathrm{~mL}$, each time for $72 \mathrm{~h}$ ). Both extracts were concentrated to dryness and stored at $-20^{\circ} \mathrm{C}$ until use.

Total saponin content

Total saponin content was estimated using the method of Li et al. [25]. The results were expressed as $\mathrm{mg}$ betulinic acid equivalents/g extract. The measurements were performed using an ABLE-JASCO V550 UVVIS spectrophotometer.

FT-IR Analysis

FT-IR spectra were recorded on an ABB MB3000 FT-IR spectrometer and were acquired over a range of $4000-650 \mathrm{~cm}^{-1}$ with 16 scans at a spectrum resolution of $4 \mathrm{~cm}^{-1}[14,33,35]$.

\section{Cell Culture}

MCF-7 (human breast adenocarcinoma), A549 (human alveolar adenocarcinoma), PC3 (human prostate adenocarcinoma), CACO2 (human colorectal adenocarcinoma) cell lines were obtained from the American Type Culture Collection (ATCC, Manassas, VA, USA). The four cell lines were routinely cultured in specific media in a humidified incubator with $5 \%$ $\mathrm{CO}_{2}$ at $37^{\circ} \mathrm{C}[13,23]$.

Cell viability assay

Cell viability was assessed using the MTT (methyl thiazolyl tetrazolium) colorimetric assay $[5,18,26]$. Briefly, the cells were plated $\left(3 \times 10^{3}\right.$ cells/well $)$ in 96-well tissue culture plates and treated with the extracts $(100 \mu \mathrm{g} / \mathrm{mL})$ for $72 \mathrm{~h}$. The absorbance, measured at $570 \mathrm{~nm}$ using a microplate reader (Wallac Victor3 1420-012), was proportional with the number of viable cells per well. $\mathrm{IC}_{50}$ value for the most active extract was further determined.

\section{Cell cycle analysis}

Cells were plated $\left(1 \times 10^{6}\right.$ cells/well $)$ in $100 \mathrm{~mm}$ plates and treated with the extracts $(100 \mu \mathrm{g} / \mathrm{mL})$ for $72 \mathrm{~h}$. Following incubation, samples were prepared as previously described using propidium iodide (PI) staining $[5,28]$ and analysed for DNA content using a flow cytometer (Guava EasyCyte ${ }^{\mathrm{TM}}$ flow cytometer). Pro-oxidant activity (DCFH-DA assay)

The pro-oxidant effect of GA extract in $\mathrm{CACO} 2$ cells was evaluated according to the method reported by Girard-Lalancette et al. [12], with some modifications [35]. Cells were plated $\left(4 \times 10^{4}\right.$ cells/well $)$ in 12 well plates and treated with the vehicle control [doubled distilled (DD) water], GA extract (100 $\mu \mathrm{g} / \mathrm{mL}$ ) for $1,2,3$ and $24 \mathrm{~h}$ or $\mathrm{H}_{2} \mathrm{O}_{2}(100 \mu \mathrm{M})$ as a positive control for $30 \mathrm{~min}$. Fluorescence intensity, which was proportional to the amount of reactive oxygen species (ROS) produced by cells, was measured in an automated plate reader (Infinite F200 PRO Tecan) (excitation wavelength $485 \mathrm{~nm}$, emission wavelength $535 \mathrm{~nm}$ ) and was compared with the positive control $\left(\mathrm{H}_{2} \mathrm{O}_{2}\right.$ - treated cells).

Statistical analysis

All experiments were performed in triplicate and the results were expressed as mean \pm SEM. Data are representative of three individual experiments. Statistical evaluation was performed using Student's $\mathrm{t}$ test; $\mathrm{p}<0.05$ was considered statistically significant.

\section{Results and Discussion}

\section{Chemical study of $G E$ and $G A$ extracts}

The total saponin content was higher in GE extract $(548.23 \pm 6.57 \mathrm{mg} / \mathrm{g})$ than in GA extract $(47.67 \pm$ $0.55 \mathrm{mg} / \mathrm{g}$ ). FT-IR analysis showed the presence of triterpenes and carbohydrates (mono-, oligosaccharides in GE extract, polysaccharides in GA extract) in both extracts and sterols in GE extract.
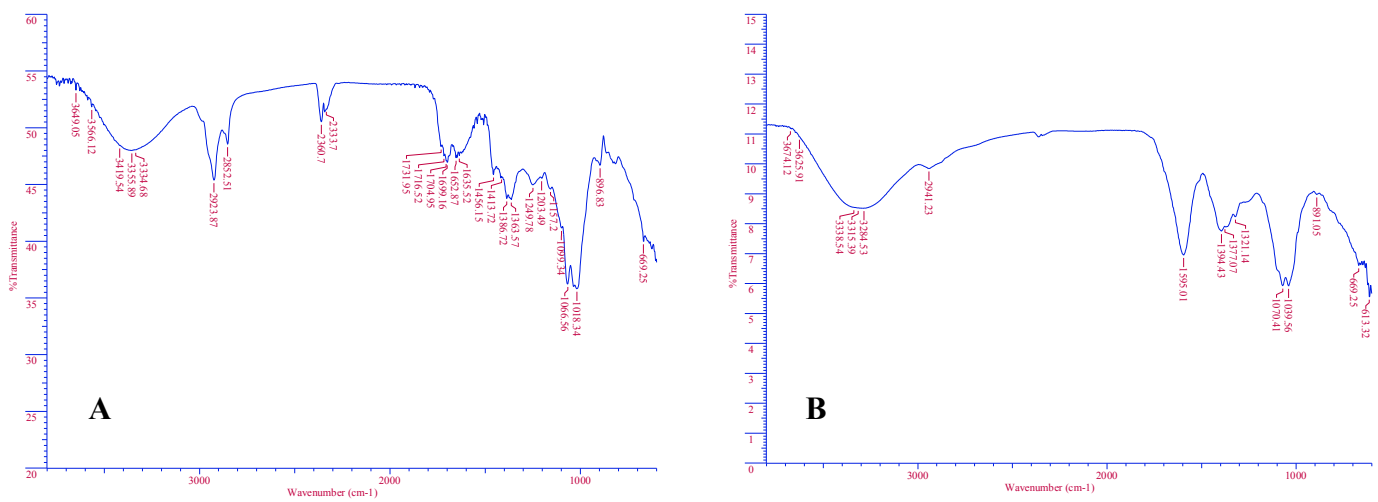

Figure 1.

(A) FT-IR spectra of GE extract, (B) FT-IR spectra of GA extract 
FARMACIA, 2019, Vol. 67, 4

Figure 1A shows the FT-IR spectra of GE extract. Characteristic absorption bands for saponins are present at $3335 \mathrm{~cm}^{-1}$ (O-H group), $2923 \mathrm{~cm}^{-1}$ (methyl group), $1704 \mathrm{~cm}^{-1}\left(\mathrm{C}=\mathrm{O}\right.$ group), $1652 \mathrm{~cm}^{-1}(\mathrm{C}=\mathrm{C}$ group $)$ and $1066 \mathrm{~cm}^{-1}$ (C-O group) [38, 39]. For sterols characteristic absorption bands are present at 3419 $3334 \mathrm{~cm}^{-1}$ (for O-H group), $2923 \mathrm{~cm}^{-1}$ (bending vibration of methyl/methylene groups), $1635 \mathrm{~cm}^{-1}$ (stretching vibration of C-C group). Characteristic band for $\mathrm{C}-\mathrm{H}$ group $\left(-\left(\mathrm{CH}_{2}\right)_{\mathrm{n}}-, \mathrm{n} \geq 4\right)$ vibration was identified at $669 \mathrm{~cm}^{-1}$ [40]. GA extract presents characteristic absorption bands for saponins at 3338 $3284 \mathrm{~cm}^{-1}, 2941 \mathrm{~cm}^{-1}, 1595 \mathrm{~cm}^{-1}$ and $1070-1039 \mathrm{~cm}^{-1}$ $[38,39]$. Absorption bands at approx. $1000 \mathrm{~cm}^{-1}(1070$ and $1039 \mathrm{~cm}^{-1}$ ) are characteristic for carbohydrates (Figure 1B) [37].

Spectral data are consistent with previous studies that reported that the aerial parts of Glinus oppositifolius contain triterpenes (glinoside A, B and C, spergulin $\mathrm{A}$ and $\mathrm{B}$ ) and carbohydrates (acidic and neutral pectic polysaccharides) $[15,16,29,31]$.

Cell viability assay

Malignant diseases are a major public health concern around the world. According to the latest statistics, one in four deaths in USA is caused by cancer. In 2012 in Europe, Ferlay et al. estimated 3.45 million of new cancer cases and 1.75 million deaths due to cancer. The most common cancers were breast cancer
(464,000 cases), followed by colorectal cancer $(447,000$ cases), prostate cancer (417,000 cases) and lung cancer (410,000 cases) [9]. Colorectal cancer is the third most common cancer in men and the second in women worldwide [11]. Cytotoxicity is considered to be the potential of a compound to induce cell death. The in vitro cytotoxicity assays are widely used as quick predictors of toxicity of new drugs in animals or humans. They also allow the reduction in animal use for toxicity testing [8].

In the present study, we investigated the antitumor effects of Glinus oppositifolius extracts on four human cancer cell lines (MCF-7, A549, PC3 and CACO2). The cells were initially exposed to $100 \mu \mathrm{g} / \mathrm{mL}$ of GA or GE extracts for $72 \mathrm{~h}$. The cytotoxic activities of the extracts are presented in Figure 2A. The negative controls (vehicle controls) were similarly processed using DMSO and DD water instead of GE and GA extracts, respectively.

The two extracts had insignificant cytotoxic effects on MCF-7, A549 and PC3 cells. In contrast, GA extract had a remarkable cytotoxic effect on $\mathrm{CACO} 2$ cells. Therefore, the effect of GA extract on $\mathrm{CACO} 2$ cells was further investigated using different concentrations ranging from 10 to $100 \mu \mathrm{g} / \mathrm{mL}$. The dose-response graph showed that GA extract had an $\mathrm{IC}_{50}$ of $97.69 \pm 2.03 \mu \mathrm{g} / \mathrm{mL}$ (Figure $2 \mathrm{~B}$ ).

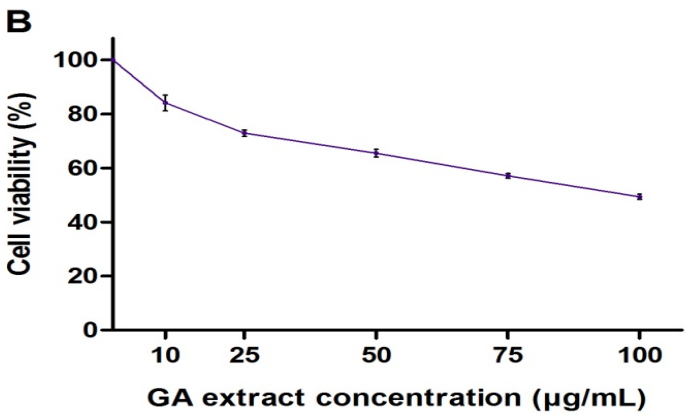

A extract concentration ( $\mu \mathrm{g} / \mathrm{mL})$

Figure 2.

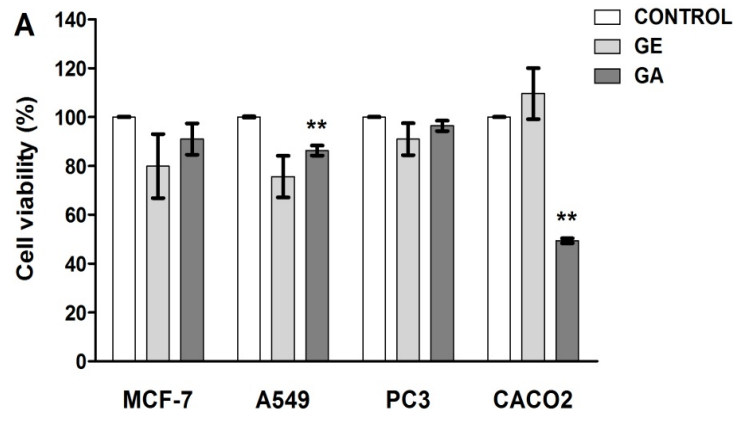

(A) Effects of Glinus oppositifolius extracts on tumor cell viability, (B) Dose-response curve for GA effect on $\mathrm{CACO} 2$ cell viability

$* * \mathrm{p}<0.005, * * * \mathrm{p}<0.0005$ compared with the controls, ${ }^{* *} \mathrm{p}_{G A}(100 \mu \mathrm{g} / \mathrm{mL})$ vs control in A549 cells $=0.003, * * * \mathrm{p}_{\text {GA }(100 \mu g / m L) \text { vs control in CACO2 cells }}<0.0001$

A similar study conducted by Boulaaba et al. showed that the methanolic extract of Arthrocnemum indicum aerial parts reduced $\mathrm{CACO} 2$ cells proliferation to approximately $55 \%$ at $100 \mu \mathrm{g} / \mathrm{mL}$ (72 h treatment) [4]. The cytotoxic effect of GA extract on CACO2 cells was slightly stronger than the one reported for the methanolic extract of Chrysanthemum coronarium L. $\left(\mathrm{IC}_{50}=106.4 \mu \mathrm{g} / \mathrm{mL} ; 72 \mathrm{~h}\right.$ treatment $)$ [1] but comparable to the one reported by Lawson-Evi et al. for the hydro-ethanolic extract of Plumeria alba L. roots $\left(\mathrm{IC}_{50}=94.5 \mu \mathrm{g} / \mathrm{mL} ; 72 \mathrm{~h}\right.$ treatment) [24].

Since GA was the sole extract showing a significant effect in reducing cell viability, only the effects of this extract (influence on cell cycle, pro-oxidant activity) were further analysed.

Cell cycle analysis

Cell death is a central mechanism controlling multicellular organism development. Apoptosis is the most common form of programmed cell death, through which intracellular activation of controlled selfdestruction occurs [2]. It is characterized by structural changes, including degradation of nuclear chromatin by fragmentation, decondensation and despiralization. Endonucleases cleave DNA phosphodiester bonds at internucleosomal linker sites [36]. It is also known that apoptosis and cell cycle arrest are closely related processes; cell cycle arrest may lead to cell death 
via apoptosis [2]. As cancer is characterized by uncontrolled cellular proliferation, there is considerable interest in treatment-induced apoptosis [19].

To elucidate whether the reduction in $\mathrm{CACO} 2$ cell viability caused by GA extract was due to the inhibition of cell cycle progression, the DNA content of CACO2 cells was determined using flow cytometric analysis after $72 \mathrm{~h}$ exposure to GA extract $(100 \mu \mathrm{g} / \mathrm{mL})$. The percentages of cells in the $\mathrm{G}_{0} / \mathrm{G}_{1}, \mathrm{~S}, \mathrm{G}_{2} / \mathrm{M}$ and sub- $\mathrm{G}_{1}$ phases were determined by measuring PI fluorescence upon binding to DNA. As shown in the histograms in Figure 3A, GA extract induced massive apoptosis in $\mathrm{CACO} 2$ cells and led to a significant accumulation of cell population in the sub-G1 phase $(55.7 \pm 4.03 \%$ vs. $8.35 \pm 3.85 \%$ in control; Figure $3 \mathrm{~B}$ ); cells in the sub-G1 phase are apoptotic, sub-diploid cells (DNA content $<2 n$ ). This was accompanied by a marked reduction in the percentages of cells in the $\mathrm{G} 0 / \mathrm{G} 1$, $\mathrm{S}$ and $\mathrm{G} 2 / \mathrm{M}$ phases (Figure 3B).

Another recent study concerning the anti-proliferative activity of the water extract from Inula viscosa (L.)
Ait. leaves on HCT116 and Colo320 human colorectal cancer cells was conducted by Bar-Shalom et al. The study revealed a significant increase of cell accumulation in sub-G1 phase in both cell lines following $72 \mathrm{~h}$ treatment (HCT116 cells: $48.47 \pm$ $5.67 \%$ vs. $5.54 \pm 1.52 \%$ in control; Colo320 cells: $40.18 \pm 4.81 \%$ vs. $5.68 \pm 1.48 \%$ in control) [3]. Daddiouaissa et al. performed a study on ionic liquid extract of Graviola (Annona muricata L.) fruits and the results showed that the treatment increased the cells in the G0/G1 phase from 59.07\% in control to $72.82 \%$ in cells treated with the extract for $72 \mathrm{~h}$, while decreasing the cells in the S and G2M phases compared with the control [7]. Boulaaba et al. reported the cell cycle arrest at the G2/M phase in CACO2 cells following $72 \mathrm{~h}$ exposure to Arthrocnemum indicum methanolic extract at $100 \mu \mathrm{g} / \mathrm{mL}(42.2 \%$ vs. 38.95\% in control) [4].

To conclude, our data demonstrate that the reduction in $\mathrm{CACO} 2$ cell viability by GA extract can be attributed, in part, to induction of apoptosis.

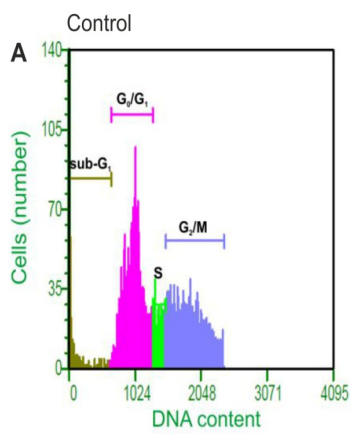

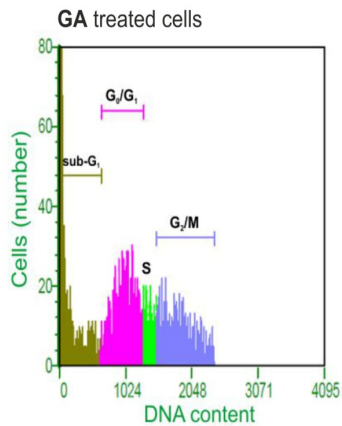

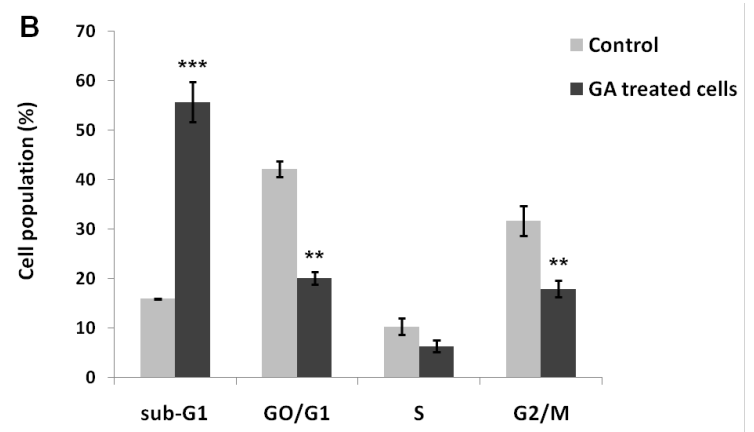

Figure 3. $* * p<0.005,{ }^{* * *} \mathrm{p}<0.0005$ compared with the controls

Pro-oxidant activity (DCFH-DA assay)

Intracellular ROS production was measured in terms of fluorescence using dichlorodihydrofluorescein diacetate (DCFH-DA). Low concentrations of ROS promote cell growth, medium concentrations induce apoptosis and high concentrations induce cell death through necrosis [20]. Schulze-Osthoff et al. and Lancaster et al. reported the mitochondrial ROS as second messengers in cell death $[22,32]$. The inhibition of mitochondrial respiratory chain leads to an increased ROS production, ROS acting as mediators of the cell death signalling pathway. In addition, ROS modulate the activity of proteins that are involved in the regulation of apoptosis such as Bcl-2 [10,34].

Figure 4 depicts the fluorescence intensities of DCF signals in CACO2 cells exposed for 1, 2, 3 and $24 \mathrm{~h}$ to GA extract $(100 \mu \mathrm{g} / \mathrm{mL})$. Pro-oxidant activity of GA extract varied in a time-dependent manner. Thus, CACO2 cells exposed to GA extract displayed an increasing fluorescence intensity of DCF signals, which indicated an increase in the production of
ROS in cells from $14.86 \pm 1.45 \%$ ( $1 \mathrm{~h}$ exposure) to $63.23 \pm 3.40 \%$ ( $24 \mathrm{~h}$ exposure). Ciani et al. reported that $24 \mathrm{~h}$ exposure of A431 human epidermoid carcinoma cells to $3 \mathrm{mg} / \mathrm{mL}$ of Uncaria tomentosa (Willd.) DC. bark aqueous extract increased intracellular ROS production to $70 \%$ [6]. Piccolella et al. reported that $72 \mathrm{~h}$ exposure of SH-SY5Y human neuroblastoma cells to $100 \mu \mathrm{g} / \mathrm{mL}$ of Pistacia lentiscus L. leaves chloroform extract increased intracellular ROS production to $93.4 \%$ [27].

Our results also suggest that another possible mechanism by which GA extract reduces CACO2 cell viability is an increase in the intracellular oxidative stress. 
FARMACIA, 2019, Vol. 67, 4

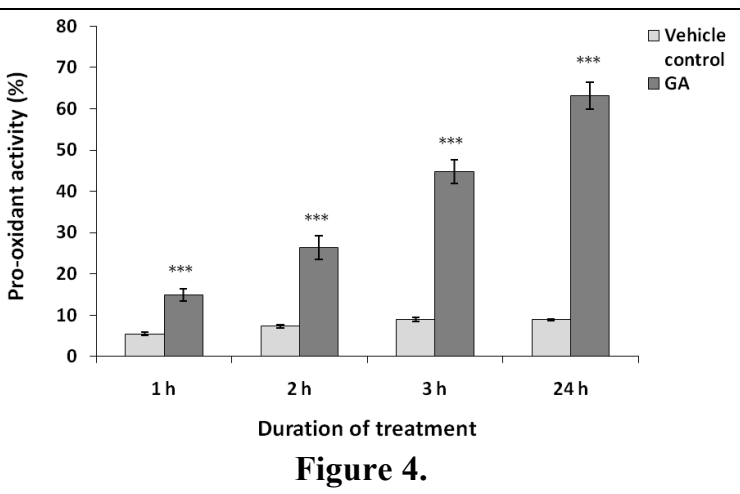

Pro-oxidant activity of GA extract in $\mathrm{CACO} 2$ cells $* * * \mathrm{p}<0.0005$

\section{Conclusions}

Antitumor screening of Glinus oppositifolius extracts revealed that the aqueous extract reduced $\mathrm{CACO} 2$ tumour cell viability to $49.36 \pm 0.97 \%$ at the concentration of $100 \mu \mathrm{g} / \mathrm{mL}$. One of the mechanisms by which the extract reduced $\mathrm{CACO} 2$ cell viability was the induction of apoptosis. In addition, the extract increased the intracellular oxidative stress in CACO 2 cells. Further in vitro studies are necessary to elucidate other mechanisms by which the aqueous extract reduces tumour cell viability. Sub-fractionation of the extract may reveal the presence of novel compounds with antitumor activity.

\section{Acknowledgement}

Authors are grateful to Prof. Dr. Berit Smestad Paulsen (University of Oslo, Norway) and Prof. Dr. Drissa Diallo (Department of Traditional Medicine, Bamako, Mali) for providing the plant material.

\section{References}

1. Abu-Rish EY, Kasabri V, Hudaib MM, Mashalla SH, Alalawi LH, Tawaha K, Mohammad MK, Mohamed YS, Bustanji Y, Evaluation of antiproliferative activity of some traditional anticancer herbal remedies from Jordan. Trop J Pharm Res., 2016; 15(3): 469-474.

2. Alberts B, Johnson A, Lewis J, Raff M, Roberts K, Walter P, Molecular biology of the cell. 5th edition. Garland Science, Taylor \& Francis Group, LLC, New York, 2008; 1115-1130.

3. Bar-Shalom R, Bergman M, Grossman S, Azzam $\mathrm{N}$, Sharvit L, Fares F, Inula viscosa extract inhibits growth of colorectal cancer cells in vitro and in vivo through induction of apoptosis. Front Oncol., 2019; 9: 1-14.

4. Boulaaba M, Mkadmini K, Tsolmon S, Han J, Smaoui A, Kawada K, Ksouri R, Isoda H, Abdelly C, In vitro antiproliferative effect of Arthrocnemum indicum extracts on Caco-2 cancer cells through cell cycle control and related phenol LC-TOF-MS identification. Evid Based Complement Alternat Med., 2013; 2013: 1-11.

5. Charalambous C, Pitta CA, Constantinou AI, Equol enhances tamoxifen's anti-tumor activity by induction of caspase-mediated apoptosis in Mcf-7 breast cancer cells. BMC Cancer, 2013; 13(238): 1-10.

6. Ciani F, Tafuri S, Troiano A, Cimmino A, Fioretto BS, Guarino AM, Pollice A, Vivo M, Evidente A, Carotenuto D, Calabrò V, Anti-proliferative and pro-apoptotic effects of Uncaria tomentosa aqueous extract in squamous carcinoma cells. J Ethnopharmacol., 2018; 211: 285-294.

7. Daddiouaissa D, Amid A, Kabbashi NA, Fuad FaA, Elnour AM, Epandy MaKMS, Antiproliferative activity of ionic liquid-graviola fruit extract against human breast cancer (Mcf-7) cell lines using flow cytometry techniques. J Ethnopharmacol., 2019; 236: 466-473.

8. Eisenbrand G, Pool-Zobel B, Baker V, Balls M, Blaauboer BJ, Boobis A, Carere A, Kevekordes S, Lhuguenot JC, Pieters R, Kleiner J, Methods of in vitro toxicology. Food Chem Toxicol., 2002; 40(2-3): 193-236.

9. Ferlay J, Steliarova-Foucher E, Lortet-Tieulent J, Rosso S, Coebergh JWW, Comber H, Forman D, Bray F, Cancer incidence and mortality patterns in Europe: Estimates for 40 countries in 2012. Eur J Cancer., 2013; 49: 1374-1403.

10. Fleury C, Mignotte B, Vayssière JL, Mitochondrial reactive oxygen species in cell death signaling. Biochimie, 2002; 84: 131-141.

11. Gavrilas LI, Ionescu C, Balacescu O, Revnic C, Ciobarca D, Filip L, Boboia A, Miere D, Foods and food groups associated with colorectal cancer: A case-control study. Farmacia, 2018; 66(5): 846-852.

12. Girard-Lalancette K, Pichette A, Legault J, Sensitive cell-based assay using dcfh oxidation for the determination of pro- and antioxidant properties of compounds and mixtures: Analysis of fruit and vegetable juices. Food Chem., 2009; 115(2): 720-726.

13. Graves TG, Harr MW, Crawford EL, Willey JC, Stable low-level expression of p21WAF1/CIP1 in A549 human bronchogenic carcinoma cell line-derived clones down-regulates E2F1 mRNA and restores cell proliferation control. Mol Cancer, 2006; 5(1): 1-13.

14. Imre S, Muntean DL, Principles of drug analysis (available in Romanian). University Press - TârguMureş, Târgu-Mureş, 2006; 89-113.

15. Inngjerdingen $\mathrm{KT}$, Debes $\mathrm{SC}$, Inngjerdingen $\mathrm{M}$, Hokputsa S, Harding SE, Rolstad B, Michaelsen TE, Diallo D, Paulsen BS, Bioactive pectic polysaccharides from Glinus oppositifolius (L.) Aug. DC., a Malian medicinal plant, isolation and partial characterization. J Ethnopharmacol., 2005; 101(1-3): 204-214.

16. Inngjerdingen KT, Kiyohara $\mathrm{H}$, Matsumoto $\mathrm{T}$, Petersen $\mathrm{D}$, Michaelsen TE, Diallo D, Inngjerdingen $\mathrm{M}$, Yamada H, Paulsen BS, An immunomodulating pectic polymer from Glinus oppositifolius. Phytochemistry, 2007; 68: 1046-1058.

17. Inngjerdingen KT, Patel TR, Chen X, Kenne L, Allen S, Morris GA, Harding SE, Matsumoto T, Diallo D, Yamada H, Michaelsen TE, Inngjerdingen M, Paulsen BS, Immunological and structural properties of a pectic polymer from Glinus oppositifolius. Glycobiology, 2007; 17(12): 1299-1310.

18. Ivănescu $\mathrm{B}$, Tuchilus $\mathrm{C}$, Corciovă $\mathrm{A}$, Lungu $\mathrm{C}$, Mihai CT, Gheldiu AM, Vlase L, Antioxidant, antimicrobial and cytotoxic activity of Tanacetum vulgare, Tanacetum 
FARMACIA, 2019, Vol. 67, 4

corymbosum and Tanacetum macrophyllum extracts. Farmacia, 2018; 66(2): 282-288.

19. Jiménez S, Gascón S, Luquin A, Laguna M, AncinAzpilicueta C, Rodríguez-Yoldi MJ, Rosa canina extracts have antiproliferative and antioxidant effects on Caco-2 human colon cancer. PLoS ONE, 2016; 11(7): e0159136.

20. Johar D, Roth J, Bay G, Walker J, Kroczak T, Los M, Inflammatory response, reactive oxygen species, programmed (necrotic-like and apoptotic) cell death and cancer. Rocz Akad Med Bialymst Supl., 2004; 49: 31-39.

21. Kandar CC, Haldar PK, Gupta M, Mazumder UK, Effect of methanol extracts of Glinus oppositifolius and Trianthema decandra in mouse against Ehrlich ascites carcinoma cell line in vivo. J Pharm Sci Tech., 2012; 2(1): 26-30.

22. Lancaster JR, Laster SM, Gooding LR, Inhibition of target cell mitochondrial electron transfer by tumor necrosis factor. FEBS Lett., 1989; 248(1,2): 169-174.

23. Langdon SP, Methods in molecular medicine, vol. 88: Cancer cell culture, methods and protocols. Humana Press Inc., Totowa, 2004; 3-15.

24. Lawson-Evi P, Diallo A, Bakoma B, Moukha S, EkluGadegbéku K, Aklikokou K, Creppy E, Gbéassor M, Cytotoxicity of plant extract on Neuro-2a, Caco-2 and Vero cell lines by using MTT assay and Neutral Red uptake test. Ann of Pharma Res., 2015; 3(7): 129-131.

25. Li X, Lin J, Han W, Antioxidant ability and mechanism of rhizoma Atractylodes macrocephala. Molecules, 2012; 17: 13457-13472.

26. Mosmann T, Rapid colorimetric assay for cellular growth and survival: Application to proliferation and cytotoxicity assays. J Immunol Methods, 1983; 65: 55-63.

27. Piccolella S, Nocera $\mathrm{P}$, Carillo $\mathrm{P}$, Woodrow $\mathrm{P}$, Greco V, Manti L, Fiorentino A, Pacifico S, An apolar Pistacia lentiscus L. leaf extract: GC-MS metabolic profiling and evaluation of cytotoxicity and apoptosis inducing effects on SH-SY5Y and SK-N-BE(2)C cell lines. Food Chem Toxicol, 2016; 95: 64-74.

28. Pitta CA, Papageorgis $\mathrm{P}$, Charalambous $\mathrm{C}$, Constantinou AI, Reversal of ER- $\beta$ silencing by chromatin modifying agents overrides acquired tamoxifen resistance. Cancer Lett., 2013; 337(2): 167-176.
29. Ragasa CY, Espineli DL, Mandia EH, Don MJ, Shen CC, A new triterpene from Glinus oppositifolius. Chin J Nat Med., 2012; 10(4): 284-286.

30. Sahakitpichan P, Disadee W, Ruchirawat S, Kanchanapoom T, L-(-)-(N-trans-Cinnamoyl)-arginine, an acylamino acid from Glinus oppositifolius (L.) Aug. DC. Molecules, 2010; 15(9): 6186-6192.

31. Sahu NP, Koike K, Banerjee S, Achari B, Nikaido T, Triterpenoid saponins from Mollugo spergula. Phytochemistry, 2001; 58: 1177-1182.

32. Schulze-Osthoff K, Bakker AC, Vanhaesebroeck B, Beyaert R, Jacob WA, Fiers W, Cytotoxic activity of tumor necrosis factor is mediated by early damage of mitochondrial functions. J Biol Chem., 1992; 267(8): 5317-5323.

33. Silverstein RM, Webster FX, Kiemle DJ, Spectrometric identification of organic compounds. $7^{\text {th }}$ edition. John Wiley \& Sons, New York, 2005; 72-126.

34. Sreelatha S, Jeyachitra A, Padma PR, Antiproliferation and induction of apoptosis by Moringa oleifera leaf extract on human cancer cells. Food Chem Toxicol., 2011; 49(6): 1270-1275.

35. Vasincu A, Paulsen BS, Diallo D, Vasincu I, Aprotosoaie AC, Bild V, Charalambous C, Constantinou AI, Miron A, Gavrilescu CM, Vernonia kotschyana roots: Therapeutic potential via antioxidant activity. Molecules, 2014; 19: 19114-19136.

36. Wang D, Wang S, Feng Y, Zhang L, Li Z, Ma J, Luo Y, Xiao W, Antitumor effects of bulbus Fritillariae cirrhosae on Lewis lung carcinoma cells in vitro and in vivo. Ind Crops Prod., 2014; 54: 92-101.

37. Wang Y, Wang P, Xu C, Yang Y, Li J, Chen T, Li Z, Cui W, Zhou Q, Sun S, Macro-fingerprint analysisthrough-separation of licorice based on FT-IR and 2DCOS-IR. J Mol Struct., 2014; 1070: 1-9.

38. Zhou H, Wang CZ, Ye JZ, Chen HX, New triterpene saponins from the seed cake of Camellia oleifera and their cytotoxic activity. Phytochem Lett., 2014; 8: 46-51.

39. Zhou Y, Zeng K, Zhang J, Li N, Chai X, Jiang Y, $\mathrm{Tu} \mathrm{P}$, Triterpene saponins from the roots of Ilex pubescens. Fitoterapia, 2014; 97: 98-104.

40. Zhu QL, Shao R, Dong R, Yun Z, An integrated approach for obtaining biodiesel, sterols, gossypol, and raffinose from cottonseed on a biorefinery concept. Energy, 2014; 70: 149-158. 